\title{
Pengembangan Media Pembelajaran Puzzle Angka untuk Meningkatkan Kemampuan Mengenal Lambang Bilangan Pada Anak Kelompok B
}

\author{
Ni Made Intan Asri Devi ${ }^{*}$ iD \\ ${ }^{1}$ Prodi Pendidikan Guru Pendidikan Anak Usia Dini, Universitas Pendidikan Ganesha, Singaraja, Indonesia \\ *Corresponding author: madeintanasri@gmail.com
}

\section{Abstract}

Penelitian ini merupakan penelitian pengembangan yang berorientasi pada suatu produk yang dikembangkan. Rendahnya kemampuan anak usia dini dalam mengenal lambang bilangan serta meningkatkan minat belajar anak didalam kelas dengan berbantuan media pembelajaran, sehingga produk yang dikembangkan dalam penelitian ini berupa media pembelajaran puzzle angka. Penelitian pengembangan ini bertujuan untuk mengembangkan suatu media pembelajaran puzzle angka untuk meningkatkan kemampuan mengenal lambang bilangan terhadap siswa kelompok B serta untuk mengetahui tingkat kelayakan penggunaan media pembelajaran puzzle angka dari ahli desain media pembelajaran, ahli materi dan mendapat respon penggunaan produk dari guru kelompok B. Penelitian pengembangan ini menggunakan model ADDIE yang terdiri dari lima tahapan, yaitu tahap Analysis, Design, Development, Implementation dan Evaluation. Penelitian ini melibatkan ahli materi dan ahli desain media pembelajaran sebagai validator. Subyek dalam penelitian ini adalah lima orang guru kelompok B. Hasil uji coba terhadap validator ahli materi dengan persentase skor 73,00\% yang termasuk dalam kategori baik dengan keterangan layak. Validator ahli desain media pembelajaran dengan persentase skor $92,50 \%$ yang termasuk dalam kategori sangat baik dengan keterangan sangat layak. Respon penggunaan produk dari lima orang guru kelompok B dengan persentase $90,80 \%$ yang termasuk dalam kategori sangat baik dengan keterangan sangat layak. Berdasarkan hasil ujicoba tersebut dinyatakan bahwa media pembelajaran puzzle angka yang telah dikembangkan dapat digunakan di TK sebagai media pembelajaran, serta mempermudah belajar siswa dalam mengenal lambang bilangan.

Keywords: Media Pembelajaran, Puzzle, Lambang Bilangan

\section{Abstract}

This research is a development research that is oriented to a product being developed. The low ability of early childhood in recognizing number symbols and increasing children's interest in learning in the classroom with the help of learning media, so that the product developed in this study is a numeric puzzle learning media. This development research aims to develop a number puzzle learning media to improve the ability to recognize number symbols for group B students and to determine the feasibility level of using numeric puzzle learning media from instructional media design experts, material experts and to get a response to product use from group B teachers. This development uses the ADDIE model which consists of five stages, namely the Analysis, Design, Development, Implementation and Evaluation stages. This study involved material experts and instructional media design experts as validators. The subjects in this study were five teachers of group B. The results of the trial of the material expert validator with a score of $73.00 \%$ were included in the good category with appropriate information. The validator is an expert in learning media design with a score of $92.50 \%$ which is included in the very good category with very decent information. The response to product use from five teachers of group B with a percentage of $90.80 \%$ is included in the very good category with very decent information. Based on the test results, it is stated that the learning media for the number puzzle that has been developed can be used in kindergarten as a learning medium, as well as making it easier for students to learn about number symbols.

Keywords: Learning Media, Puzzles, Number Symbols

$\begin{array}{ll}\text { History: } & \text { Publisher: Undiksha Press } \\ \text { Received : 25 Juni } 2020 & \text { Licensed: This work is licensed under } \\ \text { Revised : 1 Juli } 2020 & \text { a Creative Commons Attribution 3.0 License } \\ \text { Accepted : 26 Juli } 2020 & \text { CC OP OP } \\ \text { Published : } 30 \text { Juli } 2020 & \end{array}$




\section{Introduction}

Pentingnya pembelajaran matematika bagi anak sejak dini akan sangat berpengaruh terhadap kecerdasan logika matematika pada setiap anak atau individu, karena berhitung dalam matematika sering kali dijumpai maupun digunakan dalam kehidupan sehari-hari (Basri, 2018). Dengan demikian perlu adanya pengenalan angka dan lambang bilangan sejak usia dini, agar setiap anak atau individu memiliki kemampuan maupun kesiapan dalam mengenal lambang bilangan untuk berhitung. Nur (2020) menyatakan bahwa kemampuan kognitif sangat berkaitan dengan tingkat kecerdasan (intelegensi) yang dimiliki pada setiap individu yang mencirikan seseorang dengan berbagai minat terutama sekali ditujukan kepada ide-ide dan minat belajar. Menurut Hidayat dan Eka Cahya Maulidiah (2016) Kognitif merupakan suatu proses berpikir, yaitu kemampuan yang dimiliki dalam setiap individu untuk dapat menilai, mempertimbangkan dan menghubungkan suatu peristiwa maupun kejadian.

Rendahnya kemampuan anak usia dini dalam mengenal lambang bilangan sering beranggapan bahwa pembelajaran yang berkaitan dengan angka atau bilangan adalah mata pelajaran yang sangat sulit untuk dipahami (Bujuri, 2018). Dengan berbagai cara yang telah dilakukan oleh tenaga pendidik untuk mengajarkan materi-materi pembelajaran matematika dasar untuk anak usia dini yang berkaitan dengan angka, hitungan, bilangan serta yang lainnya dimulai dengan cara pembelajaran konvensional dimana proses pembelajaran tersebut menggunakan metode ceramah yaitu penyampaian secara lisan antara guru dengan siswa dan menggunakan alat bantu berupa media pembelajaran untuk dapat menarik perhatian anak selama proses pembelajaran di dalam kelas agar dapat dengan mudah dipahami (Syafitri, 2018).

Berdasarkan hasil observasi dan wawancara yang peneliti lakukan pada tanggal 11 Desember 2019 di TK Widya Kumara Tirta pada anak kelompok B yang terdiri dari 3 kelas, dengan jumlah anak dari masing-masing kelas sebanyak 16 orang dan pencapaian perkembangan dalam mengenal lambang bilangan dengan observasi kegiatan pembelajaran di sekolah. Proses pembelajaran di TK Widya Kumara Tirta menggunakan proses pembelajaran konvensional yang merupakan proses pembelajaran menggunakan metode ceramah sebagai alat komunikasi lisan antara guru dengan anak didik selama proses pembelajaran berlangsung di dalam kelas. Sehingga peneliti ingin meningkatkan minat belajar anak di dalam kelas dan meningkatkan kemampuan anak dalam mengenal lambang bilangan menggunakan media pembelajaran puzzle angka.

Sekitar $60 \%$ anak kurang mampu menyebutkan lambang bilangan dengan benar secara berurut, menggunakan lambang bilangan untuk menghitung, mencocokkan bilangan dengan lambang bilangan, dan membuat urutan lambang bilangan 1-20 dengan benar. Selain itu, kurangnya penggunaan media pembelajaran sebagai alat bantu selama proses pembelajaran berlangsung, sehingga anak terlihat masih merasa sulit untuk memahami apa yang disampaikan oleh guru di dalam kelas saat proses pembelajaran berlangsung. Selain itu partisipasi dan keaktifan anak di dalam kelas sangat rendah ini disebabkan karena rendahnya kemampuan anak dalam mengenal lambang bilangan dan kurangnya media pembelajaran yang mendukung di dalam kelas. Dengan demikian anak tidak memiliki rasa percaya diri untuk menjawab pertanyaan yang diberikan oleh guru di dalam kelas yang berkaitan dengan lambang bilangan. Ini disebabkan karena pemahaman anak dalam mengenal lambang bilangan masih rendah. Kondisi ini didukung oleh hasil penelitian yang dilakukan oleh Romlah, (2018) di Taman Kanak-kanak Sekar Wangi Kedaton Bandar Lampung yang menyatakan bahwa kemampuan mengenal konsep bilangan pada anak usia dini masih sangat kurang. Berdasarkan hasil penelitian awal yang menyatakan bahwa anak diajarkan menghitung 1-5 kemudian anak menghitung tanpa benda anak sudah bisa, namun ketika 
menghitung dengan benda sekitar $40 \%$ anak belum mampu menghitung dengan benar dan tepat. Itulah salah satu kemampuan yang harus diupayakan agar meningkat. Kebanyakan anak merasa susah dan merasa kesulitan apabila belajar berhitung permulaan. Hal ini dibuktikan dari 30 anak di TK Sekar Wangi baru ada 5 anak yang mampu berhitung dengan benar secara berurutan. Pemberian pembelajarannya juga harus dengan berbagai macam cara, namun selama ini guru masih menggunakan model konvensional yaitu dengan menghitung secara lisan tanpa menggunakan alat bantu media pembelajaran. Sehingga anak mengalami kesulitan dalam mengenal konsep bilangan. Anak merasa beban apabila disuruh menghitung ini disebabkan karena anak kurang memahami materi yang disampaikan. Padahal pembelajaran di TK seharusnya tidak membebani pada anak. Diupayakan anak mampu merasa nyaman, asik, dan senang dalam belajar khususnya belajar mengenal konsep bilangan. Serta penelitian yang dilakukan oleh Sumardi (2017) pada anak kelompok A di TK Wijaya Kusumah/Kartika XIX-26 yang menyatakan bahwa kemampuan anak dalam mengenal lambang bilangan dinyatakan belum optimal. Hal ini ditandai dengan rendahnya kemampuan anak dalam meniru menulis lambang bilangan 1-20, menunjuk lambang bilangan 1-20 dengan benar, dan menghubungkan lambang bilangan dengan jumlah benda. Berdasarkan hasil observasi awal dapat diketahui bahwa penyebab kurang optimalnya kemampuan anak dalam mengenal lambang bilangan disebabkan pada proses pembelajaran yang lebih menekankan pada pemberian tugas dan guru lebih banyak menjelaskan secara lisan. Selain itu kurangnya penggunaan media pembelajaran selama proses pembelajaran berlangsung. Guru lebih sering menggunakan lembar kerja anak (LKA) dan buku tulis sebagai sarana pembelajaran sehingga pembelajaran kurang menantang bagi anak karena kurangnya media nyata yang dapat digunakan oleh anak dalam pembelajaran mengenal lambang bilangan.

Berdasarkan penjabaran masalah tersebut, pengenalan lambangan bilangan sangat penting diberikan sejak dini. Pengenalan lambang bilangan pada anak perlu diberikan sedini mungkin dengan menggunakan cara yang tepat dan sesuai dengan tahapan perkembangan anak (Romlah, 2018). Mengenalkan lambang bilangan merupakan konsep dasar matematika yang merupakan kesiapan dalam berhitung permulaan pada anak untuk memasuki jenjang pendidikan yang lebih lanjut (Reswita dan Sri Wahyuni, 2018). Pembelajaran yang berkaitan dengan mengenal lambang bilangan khususnya untuk anak usia dini hendaknya berlangsung dalam suasana yang aman, menyenangkan, penuh keceriaan dan kegembiraan agar anak tidak merasa bosan selama belajar di dalam kelas. Untuk menciptakan pembelajaran seperti itu maka dibutuhkan sebuah media atau alat bantu. Karo (2018) menyatakan bahwa dengan perbantuan menggunakan media pembelajaran sebagai alat bantu selama proses pembelajaran berlangsung diharapkan mampu menarik minat belajar anak di dalam kelas. Proses pembelajaran anak usia dini diperlukan alternatif media pembelajaran yang sesuai dengan perkembangan anak dan mampu menarik perhatian anak. Sumardi (2017) menyatakan bahwa para pendidik biasanya mengenalkan lambang bilangan kepada peserta didiknya hanya dengan menuliskan lambang bilangan dipapan tulis atau memberikan lembar kerja kepada anak (LKA) kemudian memberikan tugas untuk mengisi lembar kerja yang sudah disediakan, sehingga anak mudah merasa bosan yang akhirnya mengakibatkan pembelajaran kurang menantang bagi anak.

Hal yang sudah dijabarkan sebelumnya menjadi alasan penelitian ini mengembangkan sebuah media yang sesuai dengan karakteristik siswa serta sesuai dengan materi mengenal lambang bilangan anak, media yang akan dikembangkan adalah media puzzle angka dengan yang diharapkan dapat meningkatkan minat belajar anak dalam mengenal lambang bilangan. Sehingga anak lebih tertarik dalam mengikuti proses pembelajaran di dalam kelas dan terciptanya proses pembelajaran yang menyenangkan serta media pembelajaran yang sesuai dengan tingkat pemahaman anak. Fadlillah (2017) mengatakan bahwa media puzzle angka 
yaitu suatu alat permainan edukatif yang dapat dimanfaatkan dan digunakan sebagai media pembelajaran yang bertujuan untuk dapat menstimulasi kecerdasan matematika logis pada setiap individu. Dengan alat permainan edukatif ini anak dapat mengerti angka serta berbagai hal yang berhubungan dengan hitungan. Dalam permainan puzzle membutuhkan ketelitian dan ketepatan serta anak akan dilatih untuk memusatkan pikiran, dan berkonsentrasi saat menyusun kepingan-kepingan puzzle (Handayani, 2019). Aktivitas penggunaan media puzzle juga melibatkan koordinasi mata dan tangan dalam menyelesaikan permainan tersebut (Tanjung, 2019). Penggunaan media puzzle akan melatih anak untuk dapat melatih daya ingat, belajar sambil bermain, mengenal bentuk lambang bilangan dan dapat melatih daya fikir anak dalam menyusun kepingan-kepingan puzzle (Husna, 2017). Penggunaan media puzzle diharapkan kemampuan pada setiap individu dalam perkembangan kognitif berkembang secara optimal dan mampu mempersiapkan diri untuk melanjutkan ke jenjang pendidikan selanjutnya.

Dengan demikian peneliti merasa tertarik untuk melakukan suatu penelitian dengan aktivitas belajar yang di dukung dengan adanya media pembelajaran yaitu penggunaan media pembelajaran puzzle angka. Media puzzle angka ini diharapkan mampu untuk dapat menarik minat belajar anak dalam mengenal lambang bilangan. Dengan adanya media puzzle diharapkan dapat bermanfaat dan berguna bagi anak usia dini selama proses pembelajaran berlangsung (Elan, 2017). Melalui penggunaan media puzzle angka diharapkan anak dapat lebih mengenal lambang bilangan, mengurutkan angka 1-20 dengan benar dan anak mampu berhitung sesuai dengan urutan angka 1-20 (Gandana, 2017). Selain itu diharapkan pula pembelajaran di kelas akan terasa lebih menyenangkan bagi anak dan lebih efektif sehingga tujuan pembelajaran yang telah ditetapkan dapat tercapai dengan baik dan maksimal (Chandra, 2019). Dengan penggunaan media pembelajaran yang lebih bervariasi, siswa lebih termotivasi dan minat belajar siswa untuk memahami materi yang disampaikan akan lebih mudah dipahami. Supriyono (2018) menyatakan bahwa penggunaan media pembelajaran yang kreatif dapat menarik fokus belajar anak sehingga proses pembelajaran terasa lebih menyenangkan. Salah satu cara agar dapat meningkatkan minat belajar anak di dalam kelas yaitu adanya bantuan media pembelajaran yang kreatif dan inovatif sehingga selama proses pembelajaran berlangsung guru juga lebih mudah menyampaikan materi yang akan disampaikan terhadap peserta didik (Mar'atusholihah, 2019).

\section{Materials and Methods}

Penelitian ini termasuk dalam jenis penelitian dan pengembangan yang berorientasi pada suatu produk yang akan dikembangkan (Research and Development). Research and Development (R\&D) merupakan suatu metode penelitian yang dapat digunakan untuk menghasilkan suatu produk tertentu yang akan dikembangkan dan menguji kegunaan suatu produk (Sugiyono, 2016). Jenis penelitian dan pengembangan ini dipilih peneliti karena peneliti mengembangkan secara mandiri suatu produk yang berupa media pembelajaran. Media pembelajaran yang dikembangkan peneliti yaitu akan menghasilkan media pembelajaran puzzle angka untuk meningkatkan kemampuan mengenal lambang bilangan pada anak kelompok B di TK. Pada penelitian pengembangan ini, adapun prosedur pengembangan yang terdiri dari lima tahapan yaitu (1) Analisis, (2) Desain, (3) Pengembangan, (4) Implementasi, dan (5) Evaluasi (Pribadi, 2017).

Pada penelitian pengembangan media pembelajaran puzzle angka ini menggunakan model ADDIE yaitu pada tahap awal yang dilakukan dalam pembuatan produk ini diawali dengan menganalisis (Dewi, 2018). Pada bagian ini dilakukan analisis terhadap kebutuhan di lapangan dengan melakukan observasi dan wawancara awal terhadap hal yang digunakan oleh sekolah untuk meningkatkan kualitas pengajaran di kelas. Dengan melakukan observasi dan wawancara ditemukan kesenjangan-kesenjangan yang terjadi di TK Widya Kumara Tirta 
yang berkaitan dengan produk yang akan dikembangkan. Kurangnya media pembelajaran yang mendukung selama proses pembelajaran mengakibatkan model pembelajaran di sekolah tersebut menggunakan model pembelajaran konvensional. Sehingga berdasarkan hasil analisis kebutuhan tersebut maka media pembelajaran puzzle angka dengan materi mengenal lambang bilangan dapat dikembangkan dan dilanjutkan pada tahap selanjutnya yaitu tahap desain.

Setelah melalui tahap analisis, penelitian ini dilanjutkan dengan melakukan desain terhadap produk yang hendak dibuat. Selanjutnya dilanjutkan ke tahap development melalui beberapa tahapan, yaitu dimulai dengan proses pembuatan sketsa, dilanjutkan dengan tahap pemotongan sketsa dan pada tahap yang terakhir dilanjutkan dengan tahap pembuatan kepingan-kepingan angka serta proses pembuatan angket uji coba. Tahap keempat dalam penelitian ini yaitu tahap implementasi. Pada tahap ini produk yang sudah siap diujicobakan pada subjek uji coba yaitu lima orang guru kelompok B. Akan tetapi, terlebih dahulu produk diujicobakan pada validator untuk mendapatkan komentar mengenai media pembelajaran yang telah dibuat terkait dengan kelayakan produk tersebut jika nantinya diimplementasikan di sekolah TK.

Metode pengumpulan data yang digunakan dalam penelitian ini yaitu observasi dan penyebaran angket/kuesioner. Observasi bertujuan untuk memperoleh data yang akan digunakan pada analisis kebutuhan dalam pengembangan suatu media pembelajaran. Metode observasi dalam penelitian ini menggunakan metode observasi terbuka, dimana peneliti melakukan observasi langsung untuk mengamati secara langsung mengenai keadaan sesungguhnya yang ada di lapangan agar sesuai dengan tujuan yang didapat. Sedangkan angket/kuesioner digunakan untuk mengetahui suatu penelitian dari responden (ahli materi, ahli desain media pembelajaran dan guru) terhadap suatu media pembelajaran yang dikembangkan. Angket/kuesioner merupakan suatu teknik pengumpulan data yang digunakan dengan cara memberi pertanyaan maupun pernyataan tertulis yang diberikan kepada responden untuk dijawab (Sugiyono, 2018). Penelitian ini menggunakan kuesioner tertutup karena pada formulir kuesioner akan disediakan alternative jawaban.

Instrumen yang digunakan untuk dapat mengumpulkan data pada penelitian pengembangan ini berupa angket. Angket berupa daftar pernyataan tertulis yang harus ditanggapi oleh responden dan angket yang digunakan pada penelitian ini merupakan angket tertutup yang artinya angket sudah disediakan jawabannya sehingga responden hanya memilih jawaban yang sudah tersedia (Arikunto, 2015). Instrumen yang berupa angket disusun untuk mengetahui kelayakan suatu media pembelajaran yang dikembangkan sebagai media pembelajaran puzzle angka. Peneliti menggunakan teknik pengumpulan data dengan menggunakan instrumen berupa angket dengan aspek dan kriteria menyesuaikan dengan kriteria produk yang diinginkan, dengan pengembangan dan memodifikasi lebih lanjut disesuaikan dengan kebutuhan dan keperluan penelitian. Instrumen berupa angket ini di validasi oleh dosen, kemudian validasi instrumen ini menghasilkan angket yang dapat digunakan untuk mengumpulkan data penelitian. (Sumber: Dengan Modifikasi Peneliti).

Teknik analisis data yang digunakan dalam penelitian ini merupakan teknik analisis deskriptif kuantitatif dan kualitatif. Hasil analisis data kuantitatif yang berupa persentase kelayakan produk dan respons dari subjek penelitian tersebut. Sedangkan data kualitatif berupa suatu pernyataan terhadap tingkat kelayakan dari masing-masing aspek pada angket penilaian. Teknik analisis deskriptif kuantitatif dan kualitatif dapat dibagi menjadi dua tahap. Tahap yang pertama yaitu memaparkan hasil uji kelayakan suatu media pembelajaran puzzle angka untuk meningkatkan kemampuan mengenal lambang bilangan dari ahli materi dan ahli desain media pembelajaran. Sedangkan pada tahap kedua yaitu memaparkan mengenai respon media pembelajaran yang diimplementasikan oleh guru kelompok B. 


\section{Results and Discussion}

Penelitian ini merupakan penelitian pengembangan yang bertujuan untuk menghasilkan sebuah produk yang akan dikembangkan. Maka dalam penelitian ini dihasilkan sebuah produk berupa media pembelajaran puzzle angka yang digunakan untuk mengajarkan materi mengenal lambang bilangan pada anak kelompok B. Produk berupa media pembelajaran puzzle angka dikembangkan melalui lima tahapan, yang diawali dengan tahap Analisis, Desain, Pengembangan, Implementasi dan Evaluasi (Sari, 2017). Semua tahapan dilakukan dengan mengikuti desain penelitian yang sudah dirancang dan validasi produk yang dilakukan oleh validator dan subjek percobaan yaitu lima orang guru kelompok B yang dilakukan pada tahap pelaksanaan dengan menggunakan alat ukur dalam bentuk kuesioner tertutup yang sebelumnya di validasi oleh penilaian ahli untuk menentukan kelayakan kuesioner sebagai alat ukur (Sugiyono, 2017).

Pembelajaran mengenal lambang bilangan di TK Widya Kumara Tirta masih menerapkan model pembelajaran konvensional dalam proses pembelajarannya masih menggunakan metode ceramah sebagai alat komunikasi lisan antara guru dengan peserta didik selama proses pembelajaran berlangsung. Kurangnya alat media pembelajaran sebagai alat bantu selama proses pembelajaran berlangsung mengakibatkan anak kurang memahami apa yang disampaikan guru di dalam kelas dan kurangnya media nyata yang dapat digunakan anak untuk belajar. Sehingga peneliti ingin meningkatkan minat belajar anak di dalam kelas serta meningkatkan kemampuan anak dalam mengenal lambang bilangan menggunakan media pembelajaran puzzle angka dengan tujuan agar dapat dengan mudah dimengerti anak serta meningkatkan kreativitas dan partisipasi anak di dalam kelas selama proses pembelajaran berlangsung.

Mengembangkan sebuah media pembelajaran tidak hanya sekedar mencari dan menemukan masalah, akan tetapi harus menganalisis hal-hal di sekitar yang mempengaruhi. Sehingga akan dihasilkan sebuah media pembelajaran yang berguna dan sesuai dengan tujuan yang hendak dicapai. Hal ini juga menjadi pertimbangan bentuk media apa yang nantinya akan dikembangkan sehingga media tersebut layak untuk digunakan dalam dunia pendidikan. Berdasarkan hasil penelitian ini, peneliti mengembangkan media pembelajaran puzzle angka. Analisis kebutuhan dalam pengembangan media pembelajaran puzzle angka ini mengacu kepada kebutuhan belajar anak yaitu alternative media pembelajaran bagi anak usia dini dalam meningkatkan kemampuan mengenal lambang bilangan serta merangsang kemampuan kognitif anak untuk berkembang karena media puzzle angka ini mengajarkan anak untuk berfikir dalam menyelesaikan suatu tantangan serta melatih emosi anak dalam menyusun media puzzle dengan benar.

Tahap awal yang dilakukan dalam pembuatan produk ini diawali dengan menganalisis. Pada bagian ini dilakukan analisis terhadap kebutuhan di lapangan dengan melakukan observasi dan wawancara awal terhadap hal yang digunakan oleh sekolah untuk meningkatkan kualitas pengajaran di kelas. Dengan melakukan observasi dan wawancara ditemukan kesenjangan-kesenjangan yang terjadi di TK Widya Kumara Tirta yang berkaitan dengan produk yang akan dikembangkan. Kurangnya media pembelajaran yang mendukung selama proses pembelajaran mengakibatkan model pembelajaran di sekolah tersebut menggunakan model pembelajaran konvensional. Sehingga berdasarkan hasil analisis kebutuhan tersebut maka media pembelajaran puzzle angka dengan materi mengenal lambang bilangan dapat dikembangkan dan dilanjutkan pada tahap selanjutnya yaitu tahap desain.

Setelah melalui tahap analisis, penelitian ini dilanjutkan dengan melakukan desain media pembelajaran puzzle angka. Dimulai dari mempersiapkan materi yang sesuai dengan kurikulum di TK, dengan tujuan untuk mempermudah proses pembuatan produk ke depannya. Pada tahap desain juga diperlukan alat dan bahan yang akan digunakan dalam 
proses pembuatan media pembelajaran puzzle angka. Kemudian dilanjutkan ke tahap development dimulai dengan proses pembuatan sketsa media puzzle angka, kemudian memotong sketsa puzzle angka yang telah dibuat dilanjutkan pada tahap akhir dengan pembuatan kepingan-kepingan angka serta proses pembuatan angket penilaian uji coba untuk ahli desain media pembelajaran, ahli materi serta lima orang guru kelompok B sebagai subjek uji coba dalam penelitian ini.

Tahap keempat dalam penelitian ini yaitu tahap implementasi dengan produk yang sudah siap untuk diujicobakan kepada lima orang guru kelompok B sebagai subjek uji coba dalam penelitian ini. Tahap akhir pada penelitian ini yaitu melakukan evaluasi pada media pembelajaran. Walaupun media pembelajaran yang di buat sudah dinyatakan memenuhi standar kelayakan dari masing-masing validator dan subjek uji coba, namun berdasarkan komentar dari beberapa subjek media pembelajaran masih perlu mendapatkan perbaikan. Saran yang diberikan yaitu menambahkan gambar yang dapat dihitung sebelum memasangkan lambang bilangan yang akan di pasangkan sesuai angka dan lambang bilangan. Hal ini bertujuan agar siswa tidak hanya memasangkan angka dengan lambang bilangannya, akan tetapi siswa dapat menghitung gambar sesuai jumlah angka yang akan dipasangkan.

Tabel 4 merupakan hasil tes persentase uji kelayakan validitas dari setiap validator dan subyek dari uji coba penelitian setelah mencoba menggunakan media pembelajaran puzzle angka yang dipaparkan dalam tabel dibawah ini mengenai hasil uji kelayakan media pembelajaran.

Tabel 4. Hasil Uji Kelayakan Media Pembelajaran

\begin{tabular}{lcc}
\hline \multicolumn{1}{c}{ Hasil Uji Kelayakan } & Persentase & Keterangan \\
\hline Validator Ahli Materi & $73,00 \%$ & Layak \\
\hline Validator Ahli Desain Media Pembelajaran & $92,50 \%$ & Sangat layak \\
\hline Guru Kelompok B & $90,80 \%$ & Sangat layak \\
\hline & & (Sumber: Data Hasil Penelitian)
\end{tabular}

Setelah media pembelajaran puzzle angka dinyatakan lolos uji validitas dari validator ahli desain media pembelajaran yang merupakan dosen Universitas Pendidikan Ganesha yang memiliki kualifikasi pendidikan terakhir S2 dan kepala sekolah dari TK Widya Kumara Tirta, validator ahli materi merupakan dosen Universitas Pendidikan Ganesha yang memiliki kualifikasi pendidikan terakhir S2 dan lima orang guru kelompok B di TK sebagai subjek uji coba dalam penelitian ini.

Berdasarkan hasil validasi penerapan hasil uji coba media pembelajaran puzzle angka terhadap ahli materi yang dinilai menggunakan angket penilaian, tersebar pada skor 4 (baik) dan skor 3 (kurang baik). Dari aspek isi materi masuk dalam kriteria baik dengan persentase skor $73,00 \%$ sehingga layak untuk diterapkan di TK. Media puzzle angka diharapkan dapat membantu siswa dalam belajar mengenal lambang bilangan dengan menggunakan variasi warna yang menarik sehingga diharapkan mampu dapat menarik perhatian anak dalam belajar mengenal lambang bilangan.

Hasil validasi selanjutnya merupakan hasil dari ahli desain media pembelajaran. Berdasarkan hasil uji dari dua validator ahli desain media pembelajaran yang dinilai dengan menggunakan angket penilaian, ditemukan bahwa sebagian besar penilaian validator terhadap aspek desain media pembelajaran puzzle angka yang dibuat tersebar pada skor 5 (sangat baik) dan skor 4 (baik). Dari aspek desain media, media pembelajaran puzzle angka ini masuk dalam kriteria sangat baik dengan persentase skor 92,50\%. Desain media pembelajaran puzzle angka dibuat dengan bahan yang aman digunakan, dipadukan dengan variasi warna yang sangat menarik dan media dapat dengan mudah dibawa kemana saja dan kapan saja. 
Dengan adanya media pembelajaran puzzle angka ini, diharapkan dapat membantu siswa untuk belajar mengenal lambang bilangan dengan mudah.

Kemudian hasil validasi dilakukan pada lima orang guru kelompok B di TK, validasi dilakukan dengan cara memberikan kuesioner yang berkaitan dengan kelayakan dari media pembelajaran puzzle angka. Berdasarkan hasil uji coba terhadap lima orang guru kelompok B yang dinilai dengan menggunakan angket penilaian yang mencakup isi materi, desain produk dan manfaat dari media pembelajaran puzzle angka, maka hasil penilaian tersebar pada skor 5 (sangat baik) dan skor 4 (baik). Berdasarkan hasil dari penilaian, media pembelajaran puzzle angka ini mendapat respons yang baik dari guru kelompok B dengan persentase skor 90,80\% yang termasuk dalam kualifikasi sangat baik dengan keterangan sangat layak. Ini menyatakan bahwa respons guru terhadap media pembelajaran puzzle angka yang dikembangkan tersebut sudah baik dan media pembelajaran puzzle angka dapat digunakan sebagai media pembelajaran di sekolah TK.

Penelitian ini juga didukung oleh penelitian relevan lainnya yang sebelumnya dilakukan oleh Sholifah dan Nurhenti D Simatupang (2016) mengenai kemampuan mengenal lambang bilangan 1-10 melalui bermain puzzle 2 keping pada kelompok A di TK Tarbiyatul Athfal. Berdasarkan hasil penelitian tersebut, kemampuan mengenal lambang bilangan dengan menggunakan media puzzle 2 keping memperoleh persentase yang sangat memuaskan. Berdasarkan hasil dari penelitiannya yang menunjukkan persentase dari guru pada siklus I 65,63\% kemudian mengalami peningkatan pada siklus II menjadi 84,38\%. Temuan ini juga didukung oleh penelitian relevan yaitu penelitian yang dilakukan oleh Rahmasari (2019) upaya meningkatkan kemampuan mengenal konsep bilangan melalui model pembelajaran picture and picture pada anak kelompok A di TK Angkasa Lanud Adi Soemarmo. Berdasarkan hasil penelitian tersebut yang menyatakan bahwa kemampuan mengenal konsep bilangan pada anak memperoleh hasil pada sikus I yaitu 60,87\% kemudian pada siklus II adanya peningkatan persentase sebesar $82,61 \%$. Sehingga dapat dinyatakan bahwa nilai pada kemampuan mengenal konsep bilangan pada anak meningkat melampaui kriteria ketuntasan yang ditargetkan sebesar $75 \%$.

Selain itu, berdasarkan hasil penelitian relevan lainnya yang dilakukan oleh Sudarwati (2018) mengenai peningkatan kemampuan membilang 1-20 melalui permainan puzzle pada anak kelompok B di TK Tunas Rimba 1 Samarinda. Berdasarkan hasil penelitian tersebut menyatakan bahwa kemampuan membilang anak pada siklus I pertemuan 1, 2 dan 3 diperoleh rata-rata 44 dengan kriteria kurang sekali. Kemudian mengalami peningkatan pada siklus II pertemuan I, 2 dan 3 sebesar 43\% dengan rata-rata nilai 63 dengan kriteria cukup. Kemudian mengalami peningkatan lagi pada siklus III pertemuan 1, 2 dan 3 sebesar 19\% dengan rata-rata nilai 75 dengan kriteria baik. Sehingga diperoleh peningkatan kemampuan membilang 1-20 dari siklus I sampai siklus III sebesar 70\% dengan kriteria baik dan baik sekali telah mencapai $75 \%$.

\section{Conclusion}

Berdasarkan penelitian yang telah dilakukan dapat disimpulkan bahwa proses pengembangan dalam penelitian ini melalui lima tahapan yaitu tahap analisis, desain, pengembangan, implementasi dan evaluasi. Media pembelajaran puzzle angka yang dikembangkan layak diterapkan di sekolah TK yang bertujuan untuk meningkatkan kemampuan mengenal lambang bilangan. Adapun hasil analisis data dari validator dan subjek percobaan, yaitu berdasarkan hasil dari validator ahli materi yang menyatakan bahwa media pembelajaran puzzle angka layak untuk diterapkan di TK dengan persentase skor $73,00 \%$. Berdasarkan hasil dari validator ahli desain media pembelajaran dengan persentase skor $92,50 \%$. Dan berdasarkan hasil dari subjek percobaan yang melibatkan lima orang guru kelompok B dengan persentase skor 90,80\%. Kriteria pengambilan keputusan dalam 
penelitian ini telah disesuaikan dari (Arikunto, 2015). Berdasarkan hasil persentase skor dalam penelitian ini, dapat disimpulkan bahwa penerapan media pembelajaran puzzle angka untuk meningkatkan kemampuan mengenal lambang bilangan pada anak kelompok B dapat diterapkan di sekolah TK sebagai media pembelajaran. Adapun saran yang ditujukan kepada guru kelompok B yaitu harus dapat menggunakan media pembelajaran sebagai alat bantu selama proses pembelajaran berlangsung, agar siswa dapat dengan mudah memahami materi pembelajaran yang disampaikan. Saran terakhir yang ditujukan kepada para peneliti dan pengembangan lain, harus dapat mengembangkan media pembelajaran yang lebih menarik dan berkualitas agar proses pembelajaran dapat berlangsung sesuai dengan keinginan yaitu terciptanya suasana yang aman dan menyenangkan.

\section{References}

Arikunto, S. (2015). Dasar-dasar Evaluasi Pendidikan. Jakarta: Bumi Aksara.

Ariyanti, T. (2016). Pentingnya Pendidikan Anak Usia Dini Bagi Tumbuh Kembang Anak. Jurnal Dinamika Pendidikan Dasar, 8(1), 50-58. Retrieved from http://www.jurnalnasional.ump.ac.id/index.php/Dinamika/article/view/943.

Basri, H. (2018). Kemampuan Kognitif Dalam Meningkatkan Efektivitas Pembelajaran Ilmu Sosial Bagi Siswa Sekolah Dasar. Jurnal Penelitian Pendidikan, 18(1), 1-9. Retrieved from https://ejournal.upi.edu/index.php/JER/article/view/11054.

Bujuri, D. A. (2018). Analisis Perkembangan Kognitif Anak Usia Dsar dan Implikasinya Dalam Kegiatan Belajar Mengajar. Jurnal Ilmu Pendidikan, 9(1), 37-50. Retrieved from http://ejournal.almaata.ac.id/index.php/LITERASI/article/view/720.

Chandra, R. D. . (2019). Pengaruh Media Puzzle Terhadap Kemampuan Anak Mengenal Angka (1-10) Pada Anak Usia 4-5 Tahun di TK Nusa Indah Desa Gumuksari Kecamatan Kalisat Kabupaten Jember Tahun Pelajaran 2018/2019. Jurnal Pendidikan Anak Usia Dini, 01(01), 32-45. Retrieved from http://jurnal.unipasby.ac.id/index.php/incrementapedia/article/download/1872/1749/.

Dewi, L. (2018). Merancang Pembelajaran Menggunakan Pendekatan ADDIE Untuk Meningkatkan Kemampuan Berfikir Kritis Mahasiswa Agar Menjadi Pustakawan Yang Beretika. Jurnal Edulib, 8(1), 99-119. Retrieved from https://ejournal.upi.edu/index.php/edulib/article/view/10901/pdf

Elan, Dkk. (2017). Penggunaan Media Puzzle Untuk Meningkatkan Kemampuan Mengenal Bentuk Geometri. Jurnal PAUD Agapedia, 1(1), 66-75.

Fadlillah, M. (2017). Bermain \& Permainan. Jakarta: Kencana.

Fauziddin, M. dan M. (2018). Useful of Clap Hand Games for Optimalize Cogtivite Aspects in Early Childhood Education. Jurnal Obsesi: Jurnal Pendidikan Anak Usia Dini, 2(2), 162-169. Retrieved from https://obsesi.or.id/index.php/obsesi/article/view/76

Gandana, G. D. (2017). Peningkatan Kemampuan Mengenal Lambang Bilangan 1-10 Melalui Media Balok Cuisenaire Pada Anak Usia 4-5 Tahun Di TK AT-TOYYIBAH. Jurnal PAUD Agapedia, 1(1), 92-105. Retrieved from https://ejournal.upi.edu/index.php/agapedia/article/viewFile/7160/4760

Handayani, A. D. (2019). Penggunaan Media Puzzle dalam Pembelajaran Tematik Untuk Meningkatkan Keterampilan Berfikir Kreatif Siswa. Jurnal Pendidikan Dasar Islam, 2(1), 1-7. 
Hidayat dan Eka Cahya Maulidiah. (2016). Peningkatan Kemampuan Kognitif Anak Melalui Kegiatan Membilang Benda Sekitar. Jurnal Pendidikan Anak, 5(2), 790-797. Retrieved from https://journal.uny.ac.id/index.php/jpa/article/view/12376/8944.

Husna, N. D. (2017). Pengembangan Media Puzzle Materi Pencemaran Lingkungan di SMP Negeri 4 Banda Aceh. Jurnal Pendidikan Sains Indonesia, 05(01), 66-71. Retrieved from http://jurnal.unsyiah.ac.id/jpsi.

Karo, I. R. dan R. (2018). Manfaat Media Dalam Pembelajaran. Jurnal Pendidikan Dan Matematika, 7(1), 91-96. from http://jurnal.uinsu.ac.id/index.php/axiom/article/view/1778.

Mar'atusholihah, H. (2019). Pengembangan Media Pembelajaran Tematik Ular Tangga Berbagai Pekerjaan. Jurnal Mimbar PGSD Undiksha, 7(3), 253-260. Retrieved from https://ejournal.undiksha.ac.id/index.php/JJPGSD/article/view/19411.

Nur, L. dkk. (2020). Kemampuan Kognitif Anak Usia Dini Dalam Pembelajaran Akuatik. Jurnal Pendidikan Dan Kebudayaan, 10(1), 42-50. Retrieved from https://ejournal.uksw.edu/scholaria/article/view/2620.

Pribadi, B. (2017). Media dan Teknologi dalam Pembelajaran. Jakarta: Kencana.

Rahmasari, S. A. dkk. (2019). Upaya Meningkatkan Kemampuan Mengenal Konsep Bilangan Melalui Model Pembelajaran Picture And Picture Pada Anak Kelompok A di TK Angkasa Lanud Adi Soemarmo. Jurnal Kumara Cendekia, 7(3), 314-323. Retrieved from https://jurnal.uns.ac.id/kumara/article/view/37612.

Reswita dan Sri Wahyuni. (2018). Efektivitas Media Pasir dalam Meningkatkan Kemampuan Konsep Bilangan pada Anak Usia 5-6 Tahun di TK Aisyiyah Bengkalis. Jurnal Pendidikan, 9(1). Retrieved from https://journal.unilak.ac.id/index.php/lectura/article/view/927.

Romlah, U. (2018). Pengembangan Media Pembelajaran Puzzle Melalui Kartu Angka di Taman Kanak-kanak Sekar Wangi Kedaton Bandar Lampung. Jurnal Ilmiah Pendidikan Anak Usia Dini, 1(1), 1-17. Retrieved from http://ejournal.radenintan.ac.id/index.php/al-athfaal/article/view/2998.

Sari, W. dkk. (2017). "Pengembangan Modul Elektronik Berbasis 3D Pageflip Profesional Pada Materi Dasar Fisika Inti dan Struktur Inti Mata Kuliah Fisika Atom dan Inti. Jurnal Pendidikan Fisika, 02(01). Retrieved from https://onlinejournal.unja.ac.id/EDP/article/view/4041.

Sholifah dan Nurhenti D Simatupang. (2016). Meningkatkan Kemampuan Mengenal Lambang Bilangan 1-10 Melalui Bermain Puzzle 2 Keping. Jurnal PAUD Teratai, 05(02), 89-93. Retrieved from http://jurnalmahasiswa.unesa.ac.id/index.php/paudteratai/article/download/14850/13504.

Sudarwati, U. (2018). Peningkatan kemampuan membilang 1-20 melalui permainan puzzle pada anak kelompok B di TK Tunas Rimba 1 Samarinda Tahun Pembelajaran 2016/2017. Jurnal Warna: Jurnal Pendidikan Dan Pembelajaran Anak Usia Dini, 03(01), 20-37. Retrieved from https://jurnal.fkipuwgm.ac.id/index.php/warna/article/view/206.

Sugiyono. (2016). Metode Penelitian Kuantitatif, Kualitatif dan R\&D. Bandung: Alfabeta.

Sugiyono. (2017). Metode Penelitian Pendidikan (Pendekatan Kuantitatif, Kualitatif dan $R \& D)$. Bandung: Alfabeta. 
Sugiyono. (2018). Metode Penelitian Kuantitatif. Bandung: Alfabeta.

Sumardi, D. (2017). Peningkatan Kemampuan Anak Usia Dini Mengenal Lambang Bilangan Melalui Media Playdough. Jurnal PAUD Agapedia, 1(2), 190-201. Retrieved from https://ejournal.upi.edu/index.php/agapedia/article/view/9359.

Supriyono. (2018). Pentingnya Media Pembelajaran Untuk Meningkatkan Minat Belajar Siswa SD. Jurnal Pendidikan Dasar, 2(1), 43-48. Retrieved from https://journal.unesa.ac.id/index.php/jpd/article/view/6262/0.

Syafitri, O. Dkk. (2018). Peningkatan Kemampuan Mengenal Konsep Lambang Bilangan 110 Melalui Permainan Pohon Hitung Pada Anak Usia 4-5 Tahun di BKB PAUD Harapan Bangsa. Jurnal AL-AZHAR INDONESIA SERI HUMANIORA, 4(3), 193-205. Retrieved from https://jurnal.uai.ac.id/index.php/SH/article/view/277/262.

Tanjung, N. dan S. M. E. (2019). Upaya Meningkatkan Kemampuan Mengenal Lambang Bilangan Melalui Bermain Puzzle Jam Anak Usia 4-5 Tahun di PAUD Generasi Bangsa Pekanbaru. PAUD Lectura: Jurnal Pendidikan Anak Usia Dini, 2(02), 13-24. Retrieved from https://journal.unilak.ac.id/index.php/paud-lectura/article/view/2496. 